Legal Update

\title{
Increased use of database right against former employees
}

\section{Ewan Nettleton}

is a senior associate solicitor in the Intellectual Property Department at Bristows. He specialises in Intellectual Property Law, with an emphasis on litigation. He has an MA in Chemistry and a DPhil in Protein Chemistry and is particularly interested in matters relating to the IT and life sciences industries.

\section{Clare Cruise}

is an associate solicitor at Bristows. She specialises in employment law and advises on both contentious and non-contentious aspects of employment law.

ABSTRACT Recently, several cases have arisen dealing with employees who have attempted to take confidential information with them when leaving a job. Although departing employees are subject to a duty of confidentiality, the case law demonstrates that this duty is extremely limited once they have left. Notably, there has been a growing trend towards employers seeking to assert infringement of database right, in addition to the more traditional breaches alleged in employment cases. The most recent cases the authors have seen demonstrate that when it comes to appropriation of database information by an ex-employee, database right is becoming an important tool in the employer's armoury.

Journal of Database Marketing \& Customer Strategy Management (2009) 16, 277-281.

doi:10.1057/dbm.2009.28

Keywords: employer; employee; database right; PennWell; Crowson; First Conference

\section{INTRODUCTION}

Modern technology makes it relatively easy for employees to remove confidential information from their place of work at the end of their employment. Inevitably, some employees will be tempted to do so in order to improve their own chances of success with a new employer, or to set up a competing business of their own. Many employment contracts contain clauses to prevent employees from using confidential information that they have gained during their employment. However, in the absence of express restraints, the implied duty of confidentiality gives the ex-employer very limited protection. Faccenda Chicken Ltd $v$ Fowler $^{1}$ makes it clear that once an employee has left employment, the information will only be protected if it amounts to a trade secret or if it is of such a highly confidential nature as to require the same protection as a trade secret, which will usually be only a very narrow category of the employer's most sensitive information.

It is notable that, as reported previously, ${ }^{2}$ we have started to see employers trying to rely on database right - an intellectual property right that seeks to protect the substantial investment made in obtaining, 
presenting and verifying the contents of a database $^{3}$ - where data have been taken by an ex-employee from the employer's database, in addition to the breaches more usually alleged in employment cases. This article looks at three recent cases, evaluating how the Courts assessed the arguments raised by the employer, and takes a critical look at how useful database right can be in these situations.

\section{RECENT CASES}

\section{PennWell Publishing (UK) Ltd v. Ornstien and Ors}

This was a case that dealt with the issue of ownership of contact information. One of the Defendants, Junior Isles, was a journalist who had been employed by PennWell Publishing in what the judge described as an important role as publisher [of newsletters] and conference chairman for international conferences for the power industry. Isles had worked for PennWell for several years before he resigned. Shortly before leaving PennWell, Isles copied the contents of his Outlook address book at PennWell to a memory stick. The copied list included business contacts he had made while working for a previous employer, details of contacts he had made while working at PennWell, and personal contact details of his friends and family.

As the information consisted of individual addresses and contact details, PennWell were not able to rely on the confidentiality clause in Isles' employment contract because, in the light of Faccenda Chicken, such information was not sufficiently confidential to amount to a trade secret, and indeed much of the material was easily available in the public domain. PennWell had to show that the list belonged to them to be able to assert control over it. PennWell claimed that the contacts list was prepared and maintained on PennWell's computer system and backed up on its servers during Isles' employment, and was for the purpose of that employment. Hence, it argued, the list was confidential information that was the property of PennWell, although it conceded that Isles should be allowed to keep a copy of any part of the information that pre-dated his employment by PennWell. Isles disputed PennWell's claim on the basis that the list was his personal contacts list that he, like other journalists and editors, kept and that contained the contacts he had built up over the course of his career.

PennWell also argued later on in the proceedings that it owned rights to the contact information based on the information having been stored in a database protected by database copyright and database right.

The judge concluded that the list was not the same as a list of customer contacts simply copied or taken from an employer. Taking that sort of list would be a breach of the employee's duty of fidelity. On the other hand, the list could not properly be described as a personal list. It had been developed and was maintained by Isles for the purpose of his role at PennWell, and was stored on a programme on PennWell's email system and backed up by them. In these circumstances, the judge considered that the list belonged to PennWell.

That said, the Court accepted that Isles, being a journalist, was in a different position from that of a salesman or other business executive. Had he maintained the list as a separate private address book, to which he selectively added journalistic contacts for career purposes, he would have been entitled to develop and maintain it. Further, in the absence of a clear computer usage policy, the Court accepted that employees would be entitled to keep a separate list of personal contacts (for example, details of lawyers or doctors) that they would be able to take with them on leaving employment. However, the difficulty for Isles was that he had not only 
taken personal contacts and selected business contacts - he had copied the entire list.

The judge recognised that his conclusion that contacts lists maintained by employees on their employers' computer systems are the property of their employers would surprise many employees who keep all sorts of contact details on their employers' computer systems, and he emphasised the importance of companies putting clear computer usage policies in place to explain this to employees.

Though not considered in any detail, it was notable that, although the Judge was far from persuaded that the list was protected by database copyright (which requires a degree of creativity), his comments did suggest that it could be protected by database right. The case therefore provided a hint that database right could be important in the context of departing employees.

\section{Crowson Fabrics Limited}

\section{v. (1) Paul Rider (2) Warren Stimson} (3) Concept Textiles Limited ${ }^{5}$

This case involved two employees (Rider and Stimson) who terminated their employment at Crowson Fabrics and set up a rival fabric company, Concept Textiles Ltd ('Concept'). Their employment contracts did not contain any express clauses dealing with confidentiality or restrictive covenants. Crowson alleged that they had produced a spreadsheet of forecast sales using Crowson's confidential information and listing 3500 of Crowson's customers, that they had sent to a new Concept hotmail address a list of 70 contacts extracted from Crowson's database, and that they had retained confidential materials including customer listings, customer sales and a supplier bible.

Crowson produced documentation showing that a significant amount of activity in relation to the setting up of the new company had taken place before the employees left their employment. For example, Stimson had emailed the contacts made during his employment from his Crowson email address to tell them that he and Rider were setting up a rival fabric company, and had arranged for a junior employee from Crowson to set up a new telephone system and produce the new company letterhead. Two PowerPoint presentations showed that the employees were planning to target 500 of Crowson's key retailers and that they had signed up a number of key suppliers.

The judge held that Crowson had failed to prove that the documents were confidential to the extent that the employees should be prevented from being able to use the information in a legitimate way once their employment had terminated. However, he held that both defendants were in breach of their duty of fidelity by setting up a rival business while employed by Crowson and retaining or transferring to Concept documents belonging to Crowson with a view to using them to compete with Crowson. Furthermore, they were found to have solicited the business of Crowson's customers and diverted some business opportunities to themselves. It was no defence to the claim that the employees had breached the duty of fidelity for them to state that the information was already in the public domain.

Crowson had also alleged that Rider and Stimson had infringed its database rights by a substantial extraction of information from its computer system. It asserted that the clearest instance of this was a spreadsheet Mr Rider had created using information on Crowson's sales and transferred electronic documents from Crowson's databases. Crowson provided evidence that the investment made in the databases was sufficiently substantial for database right to subsist.

Although it must be acknowledged that the evidence on the investment being substantial was not challenged by Rider and Stimson, and that the European case law on 
this point is not wholly favourable to database right owners, ${ }^{6}$ the judge gave a very clear ruling on database right in favour of Crowson. He considered that the right subsisted, was plainly owned by Crowson, and had been infringed by the defendant's activities.

\section{First Conference Services Ltd v. (1) Richard Bracchi (2) Inspire Conferences Ltd (t/a IE Group Ltd $^{7}$}

In this case, First Conference Services Limited (First Conference) alleged that former employee Richard Bracchi had set up his own company staging conferences in competition with First Conference. First Conference claimed that Bracchi had provided his company with a 'springboard' by transferring to it large amounts of data from First Conference's database and details of its sales records, and by transferring to himself a domain name that had been purchased by First Conference. The allegations included the assertion that transfer of the data had infringed First Conference's database right.

The case was heard by the same judge (Mr Peter Smith) as the Crowson Fabrics case, and it is notable that, in addition to finding that other rights of the employer had been breached, the judge took a similarly robust line when it came to database right. He held that (once again on the basis of evidence that was not challenged by the former employee) there had been the substantial investment needed for database right to subsist, and that the right had been infringed. As the judge put it:

The information extracted by [Bracchi] from [the Claimant's] database is the large number of customer contacts, the sales information and the other material identified in the emails .... This is a case of extraction and in my view a breach of article 16(1) of the Copyright and Rights in Database Regulations 1997. It is clear that the database was created using substantial investment in obtaining, verifying or presenting its contents. Once again the investment is of human or technical resources as set out in the Claimant's evidence.

As the judge had already concluded that Bracchi had copied the databases, he made the clear finding that database right had been infringed.

\section{WHAT CAN EMPLOYERS DO TO PROTECT THE INFORMATION THEY STORE IN DATABASES?}

Lists of contacts on an employee's computer will often be a mix of the employee's personal contacts and contacts developed for the purpose of the employer's business. The case law suggests that the lists will belong to employers if generated on computer systems set up, maintained and backed up by the employer, but it is important to note that employees could still have rights to some of the contact information in certain circumstances.

Given these issues, employers should put in place a computer usage and internet policy that makes clear what may be stored and who owns the information, and emphasises that employees must keep their personal and business contacts separate.

Employers should ensure that these policies are clearly communicated to all staff both at the commencement of employment and at appropriate future intervals. Additionally, they should also inform employees of what (if any) monitoring will be put in place to ensure compliance with data protection laws.

As far as employment contracts are concerned, employers should ensure that they contain (appropriately limited) non-compete restrictions, and specifically provide that intellectual property rights (including database rights and confidential information) created by the employee 
during the course of their employment will be owned by the employer, even after employment has terminated. Reliance on common law implied terms is often fraught with difficulty, and therefore employers should ensure that they obtain tailor-made protection in the form of express covenants so that they are in the best possible position to take appropriate action, if necessary, to deal with disloyal employees and protect against financial loss caused by unlawful competitive activity.

\section{ASSERTING DATABASE RIGHT IN EMPLOYMENT CASES}

Recent cases of ex-employees departing with data from their former employers' databases demonstrate that, in addition to the perhaps more usual claims for breach of duties of fidelity and misappropriated confidential information, employers should also consider asserting infringement of database right. The employer will usually own the database, and the Courts have shown a willingness to accept the employer's evidence that the investment made in the database was substantial enough for the right to subsist, albeit this has tended not to be challenged by the exemployee. In these circumstances, as long as the part of the employer's database affected is substantial, the employer is likely to be able to rely on the right.

\section{REFERENCES AND NOTES}

[1986] 1 All E.R 617.

2 See Nettleton, E. and Ohta, T. (2009) Worth making a song and dance about database right? The Journal of Database Marketing and Consumer Strategy Management 16(3): 221-225.

3 For background on database right see for example: Nettleton, E. and Obhi, H. (2004) Legal Protection for databases in Europe: The vexed question of whether US businesses can benefit. The Journal of Database Marketing and Consumer Strategy Management 11(3): 268-273.

4 [2007] EWHC 1570 (QB); [2007] IRLR 700.

5 [2007] EWHC 2942 (Ch); [2008] IRLR 288.

6 The position on what can be counted towards the substantial investment required may cause difficulties for database owners given the European Court of Justice's findings in the British Horseracing Board and Fixtures Marketing cases as explained in Nettleton, E. and Obhi, H. (2005) ECJ rules on protection afforded by database right. The Journal of Database Marketing and Consumer Strategy Management 12(3): 266-271.

7 [2009] EWHC 2176 (Ch). 